\title{
The Effect of 8-Week Balance Training on the Agility, Strength, Balance Performance and Tennis Skills of 10-14 Year-Old Tennis Players
}

\author{
Esin Ergin (Corresponding author) \\ Department of Coaching Education, Faculty of Sport Sciences \\ Aydin Adnan Menderes University, Aydin 09100, Turkey \\ Tel: 90-256-315-3538_E-mail: esinergin7@gmail.com \\ Engin Arslan \\ EA Tennis Academy, Aydın, 09100, Turkey \\ Tel: 90-507-780-4213Ｅ-mail: arslanengin@hotmail.com
}

Received: July 29, 2020 Accepted: August 31, 2020 Published: September 7, 2020

doi:10.5296/jei.v6i2.17450ＵRL: https://doi.org/10.5296/jei.v6i2.17450

\begin{abstract}
The present study aimed to examine the effect of an 8-week balance training on the agility, strength, balance performance and tennis skills of tennis players aged 10-14. The study was participated by 19 tennis players (10 males and 9 females) playing in the EA Tennis Academy. The participants were selected randomly and divided into two groups as experimental group (9 players) and the control groups (10 players). Firstly, vertical jump, pro-agility, dynamic balance and ITN tennis skills tests were applied to all the participants. After all the test were completed, the experimental group were applied 8 weeks of balance and tennis training while the players in the control group continued tennis training only. The same tests were applied to the participants at the end of the 8 weeks. The findings of the study showed statistically significant improvement in the agility, balance index and tennis skills tests in the pre-test and post-tests of the experimental group $(p=0.034, p=0.025, p=0.003)$, whereas improvement was seen only in the tennis skills test of the control group $(\mathrm{p}=0.000)$. In addition, no statistically significant difference was found in the vertical jump performance used to determine the explosive strength both in the experimental and control groups. As for the difference between groups, a significant difference was found only in the pro-agility post-tests of the experimental and control groups $(p<0.05)$. Based on these findings, it was
\end{abstract}


revealed that balance training would improve agility and balance in 10-14 year-old children as well as contributing to their tennis skills. Therefore, it is considered that balance training should be included in training plans.

Keywords: Tennis, Balance, Tennis skills, Vertical jump, Pro-agility

\section{Introduction}

Tennis has become one of the world's most popular sports with the gradually increasing number of active athletes (Mallilou et al., 2010). Competition and success in tennis requires a number of physical characteristics like speed, agility, endurance, flexibillity and strength as well as tennis specific skills (Fernandez et al., 2009; Isha et al., 2018). Moreover, it also involves the skills of reacting fast and coping with fatigue and pressure during a match the elite adolescent player averages 2.3 hours of practice or play per day, a mean of 6.1 days a week (Barber-Westin et al., 2010). A tennis player should work on 4 characteristics to maximize his/her athletic performance. These are branch-specific physical and conditional fitness, mental quality, mobility on the court and stroke productivity (Gür \& Ersöz, 2017). Balance training was used to prevent injuries as an important part of the rehabilitation process; to re-gain neural awareness needed for necessary proprioceptor and kinesthetic skills for years (Oliver \& Brezzo, 2009). Recent studies, on the other hand, have revealed that balance and mobility are the main factors in improving athletic performance. While balance training is considerably important for the neuromuscular system in athletes, it is also reported to be among the main factors of developing athletes' performance (Zech et al., 2010). If trained correctly balance and mobility skills are expected to improve movement awareness in the body's all ranges of motion. This improvement is believed to strengthen the basis of athletic skills in all branches as well as enabling the necessary power and strength gain (Hrysomallis, 2011). Proprioception is highly important in tennis because tennis skills consist of complex moves requiring improved balance skills, and they involve multi-directional movements and explosive movements of short intervals. Physical condition in tennis is built upon focusing on the recovery time along with anaerobic energy systems, agility, balance, speed and explosion (Mallilou et al., 2010). Balance is one of the main qualities to be improved for a tennis player while a limited number of studies can be found in the literature on the subject. Kibele and Behm (2009) found a statistically significant increase in the knee extension movement, static and dynamic balance, long jump, hopping tests and shuttle run tests as a result of a 7-week balance training.

Simec et al. (2007) reported that 10-week balance training improved explosive strength and agility in physically active men. In addition, the level of balance in tennis in the children-young category is reported to cause changes in the course of the game, mistakes made by the players are caused by loss of balance under the effect of the racket and ball and balance reaching a stable position before hitting brings along fewer mistakes (Moşoi, 2012). Mallilou et al. (2010) state that tennis training alone does not improve balance performance, so balance training exercises should be included in training programs. Moreover, tennis is a branch in which direction changing skills are often used and Okudur and Sanioğlu (2012) report a positive significant relationship between agility and balance performance in 12 
year-old tennis players. Sannicandro et al. (2014) revealed that balance trainning prevent lower extremity asymmetry and protects from injuries in young tennis players.

Proprioception is known to coordinate such variables as position of movement (location), power and speed. Therefore, it helps to control the lower extremity during a tennis match. This feature makes it more important for branches like tennis that require movement skills. Knee and hip Proprioception in tennis has been revealed to be a distinctive feature of elite, amateur or novice tennis players (Lin, 2006). However, there are only a limited number of studies aiming to determine the effect of branch-specific balance training exercises on biomotor abilities and tennis performance and the subject is not yet very clear.

The objectives of this study are to determine the effect of balance training on strength, agility and balance performance and to examine the effect of balance training on tennis skills. In addition, the study aims to determine whether an 8-week training program is sufficient to improve dynamic balance.

\section{Material Method}

\subsection{Participants}

The present study was voluntarily participated by 19 (10 males and 9 females) participants aged 10-14 playing tennis in EA Tennis Academy in the city of Aydın. The participants were selected randomly and divided into two groups as the experimental group ( 9 players, $49.11 \pm 5.37 \mathrm{~kg}, 159.66 \pm 4.63 \mathrm{~cm}$ ) and control group (10 players $44.10 \pm 8.79 \mathrm{~kg}, 150.50 \pm 8.66)$. The participants have no muscular/skeletal injuries. All the participants signed the form explaining the aim and content of the study with their families' consent and filled out the sports health history inventory. The study was approved with the decision number 16 of Adnan Menderes University Faculty of Health Sciences Ethics Committee numbered with the protocol number 53043469-050.04.04.

\subsection{Procedure}

At the beginning of the study, vertical jump, pro-agility, dynamic balance and ITN tennis skills tests were applied to all the participants and then the participants in the experimental group $(\mathrm{n}=9)$ were given a tennis specific 8 -week balance training program on stable and unstable grounds. The athletes in the control group continued only tennis training exercises during 8 weeks. In order to examine the effect of explosive strength, agility and balance performance and tennis skills prior to the balance training sessions, vertical jump, reactive agility and dynamic balance tests along with the ITN tennis skills tests were applied to all the participants again. Before each test protocol, the participants practiced a warm-up program consisting of standardized 10-minute dynamic stretching exercises.

\subsection{Vertical Jump Test}

Static squat jump test was applied to assess strengths of the 10-12-year-old tennis players. The test was conducted using a jumping mat and a handheld computer (FusionSport, Austria), the athletes were asked to perform two maximal repeats with 3-minute resting intervals and the higher score was recorded. During the test, the athletes were asked to be ready on the 


\section{Macrothink}

jumping mat on both feet with their hands on their waist and their knees at $90^{\circ}$ squat (bent at $90^{\circ}$ ) and then to jump as high as they could from the position they were standing in.

\subsection{Pro-agility Test}

Participants' agility was measured with Pro Agility test. Photocell doors were placed at $60 \mathrm{~cm}$ height at the starting point with pins placed at $4.57 \mathrm{~m}$ on the right and left sides (Figure 1). Athletes setting off at maximal speed from the starting point touched one pin and changed direction to touch the other one and the test was finalized when they returned to the starting point. Their performance was tested twice with 3-minute resting intervals and the better score was recorded.

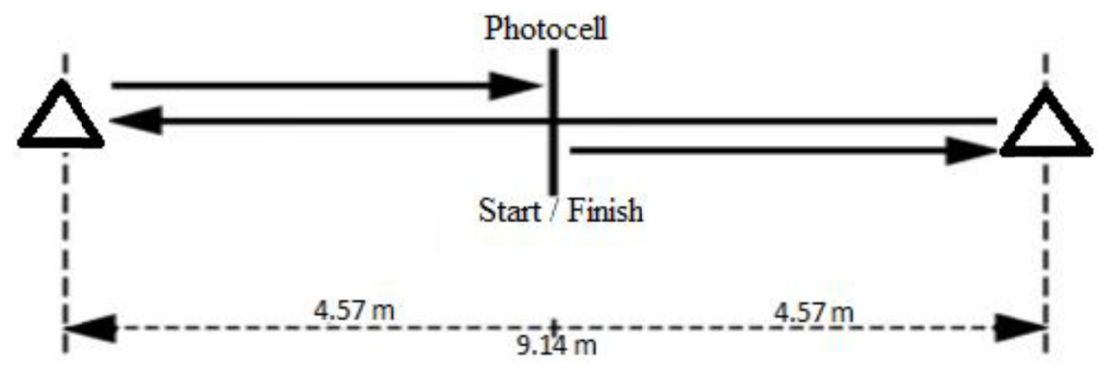

Figure 1. Pro-agility Test (Vescovi \& VanHeest, 2010)

\subsection{Dynamic Balance Test}

A device produced by EasyTech (a computer placed on a platform of $43 \mathrm{~cm}$ length, $42 \mathrm{~cm}$ width and $65 \mathrm{~cm}$ height) was used to measure dynamic balance. Easy dynamic balance system is composed of a platform and a computer to control the system. The system is completed by connecting the balance platform to the USB interface EasyTech 2.2001-2.0 computer software. The lower platform of the dynamic balance system platform can be set to difficulty levels of $10 \mathrm{~cm}, 25 \mathrm{~cm}$ and $40 \mathrm{~cm}$ from difficult to easy with a plastic apparatus. In the present study, difficulty level was arranged with the $40 \mathrm{~cm}$ apparatus. The test was performed with both feet, for 30 seconds at level 9. Easytech software obtains the angular changes in the position of the device against the ground and time from the swinging balance platform while using the parameters of total area, external area, external time and recovery time. The present study employed the data obtained from the device together with the scores estimated on the index of balancing precision (Tchorzewski et al., 2013).

$$
\text { Indexing of Balancing Precision }(\mathrm{IBP})=(\mathrm{EA} / \mathrm{TA}) \times 100
$$

Calculated using the formula: $\mathrm{EA}=\sqrt{\text { External area right }}+\sqrt{\text { External area left }}, \mathrm{TA}=$ $\sqrt{\text { Total area right }}+\sqrt{\text { Total area left }}$ (Tchorzewski et al., 2013).

\subsection{ITN Tennis Skills Test}

ITN, stands for the phrase International Tennis Number. It is a practice that was started by the 
International Tennis Federation in order to determine game levels of those who play tennis around the world. It is possible to find an ITN number appropriate for the degree of players of all levels from the beginner level to professionals. When conducting this test, instead of the technical properties of individuals' tennis strokes; stability, depth and power elements of their services, groundstrokes and volleys in their 5 game states are evaluated as well as their physical mobility qualities. In the present study, depth, power and precision strokes in the ITN test were limited to skills test measurement method for forehand and backhand tennis skills. (a) Groundstrokes depth and power test; Calculated over the total sum of the scores obtained from 10 balls stroke to the farthest area of the tennis court. (b) Groundstrokes precision and power test; In this test, players are asked to strike 6 balls ( 3 forehand-3 backhand) to the farthest point from the parallel court area and 6 balls (3 forehand-3 backhand) to the farthest point from the cross court area (Seyrek et al., 2017).

\subsection{Balance Training Program}

After the participants completed the tests, the experimental group participated in the balance training program 3 times a week during 8 weeks in addition to the tennis training whereas the players in the control group continued tennis training only. Balance training programs were designed so as to include tennis specific movements on stable and unstable grounds. Unstable grounds were provided by using a bosu, wobble board and balance pad. The content of the 8 -week balance training program applied to the participants within the scope of the study is given in Table 1.

Table 1. Content of the 8-week balance training

\begin{tabular}{|l|l|l|l|}
\hline \multicolumn{5}{|l|}{ TRAINING CONTENT } \\
\hline Week 1 & $\begin{array}{l}\text { Basic Balance Stances } \\
\text { on Hard Ground }\end{array}$ & $\begin{array}{l}\text { Basic Balance Stances } \\
\text { on Hard Ground }\end{array}$ & $\begin{array}{l}\text { Basic Balance Stances } \\
\text { on Hard Ground }\end{array}$ \\
\hline Week 2 & $\begin{array}{l}\text { Single/Double feet balance } \\
\text { on Wobble Board Standing }\end{array}$ & $\begin{array}{l}\text { Touch on targets on } \\
\text { Wobble Board }\end{array}$ & Walks on Wobble Board \\
\hline Week 3 & $\begin{array}{l}\text { Ball control with racquet } \\
\text { on Wobble Board }\end{array}$ & $\begin{array}{l}\text { Forehand strokes on } \\
\text { Wobble Board }\end{array}$ & $\begin{array}{l}\text { Backhand strokes } \\
\text { on Wolbble Board }\end{array}$ \\
\hline Week 4 & $\begin{array}{l}\text { Stance on Bosu Single/Double } \\
\text { Feet Balance Stances }\end{array}$ & $\begin{array}{l}\text { Jumps/Turns on Bosu } \\
\text { on Bosu }\end{array}$ & $\begin{array}{l}\text { Ball control with } \\
\text { racquet on Bosu }\end{array}$ \\
\hline Week 6 & $\begin{array}{l}\text { Ball control with racquet } \\
\text { on Bosu }\end{array}$ & $\begin{array}{l}\text { Forehand strokes on } \\
\text { Balance Pad }\end{array}$ & Backhand strokes on Bosu \\
\hline Week 7 & Walks on Balance Pad & $\begin{array}{l}\text { Forehand-backhand strokes } \\
\text { on balance pad }\end{array}$ & $\begin{array}{l}\text { Backhand strokes } \\
\text { on Balance Pad }\end{array}$ \\
\hline Week 8 & $\begin{array}{l}\text { Juggling. Controlling the ball } \\
\text { on Bosu and Balance pad }\end{array}$ & $\begin{array}{l}\text { Forehand-Backhand strokes } \\
\text { on Bosu and Balance Pad }\end{array}$ & $\begin{array}{l}\text { Double stroke drills } \\
\text { on Bosu and balance pad }\end{array}$ \\
\hline
\end{tabular}




\section{MInstitute ${ }^{\text {Macrothink }}$}

\subsection{Statistical Analysis}

The data were analyzed using SPSS 20.0 package program. Shapirowilk test was conducted for normality in distribution between groups. Student $T$ test was applied to the normally distributed data for the variables between groups, and the statistical assessment of the difference between repeated measures was performed using Paired $\mathrm{T}$ Test for each group. Level of significance was accepted as $(\mathrm{p}<0.05)$.

\section{Findings}

The present study aimed to determine the effect of 8-week balance training exercises on 10-14 year-old tennis players' agility, strength, balance performance and tennis skills. The results of the Paired Samples $T$ test showing the statistical difference between the balance index, agility, explosive strength and ITN tennis skills pre-test results are presented in Table 2.

Table 2. Difference between the balance index, agility and explosive strength pre-test results of the experimental and control groups

\begin{tabular}{|l|l|l|l|l|l|l|}
\hline \multirow{2}{*}{} & \multicolumn{2}{|c|}{ Balance Training Group $(\mathbf{n}=9)$} & \multicolumn{3}{c|}{ Control group (n= 10) } \\
\cline { 2 - 7 } & pre & post & $\boldsymbol{p}$ & pre & post & $\boldsymbol{p}$ \\
\hline Vertical Jump & $31.20 \pm 6.27$ & $31.20 \pm 4.79$ & .906 & $26.94 \pm 4.20$ & $27.85 \pm 2.42$ & .341 \\
\hline Pro-agility & $5.83 \pm 0.24$ & $5.54 \pm 0.33$ & $.034^{*}$ & $6.33 \pm 0.45$ & $6.07 \pm 0.34$ & .052 \\
\hline Balance Index & $68.31 \pm 7.83$ & $62.45 \pm 6.17$ & $.025^{*}$ & $67.73 \pm 14.09$ & $65.94 \pm 9.40$ & .773 \\
\hline ITN & $138.22 \pm 34.12$ & $160.55 \pm 23.90$ & $.003^{*}$ & $134.80 \pm 32.23$ & $172.30 \pm 29.36$ & $.000^{*}$ \\
\hline
\end{tabular}

Note. ${ }^{*} p<0.05$.

While a statistically significant progress is seen in the agility, balance index and tennis skills tests of the experimental group, only tennis skills improved in the control group in the pre and posttests. On the other hand, no statistically significant difference was found in the vertical jump performance that is used to determine the explosive strength both in the experimental and control groups.

The results of the Student $\mathrm{T}$ Test which is used to reveal the difference in the qualities examined between the groups are shown in Table 3. 
Table 3. Differences in the dynamic index, agility, explosive strength and ITN test between the experimental group and control group

\begin{tabular}{|l|l|l|l|}
\hline & Balance Training Group $(\mathbf{n}=\mathbf{9})$ & Control Group $(\mathbf{n}=\mathbf{1 0})$ & $\boldsymbol{p}$ \\
\hline Vertical Jump Pre-test & $31.20 \pm 6.27$ & $26.94 \pm 4.20$ & 0.12 \\
\hline Vertical Jump Post test & $31.20 \pm 4.79$ & $27.85 \pm 2.42$ & 0.08 \\
\hline Pro-agility Pre-Test & $5.83 \pm 0.24$ & $6.33 \pm 0.45$ & 0.09 \\
\hline Pro-agility Post Test & $5.54 \pm 0.33$ & $6.07 \pm 0.34$ & $0.03 *$ \\
\hline Balance Index Pre Test & $68.31 \pm 7.83$ & $67.73 \pm 14.09$ & 0.91 \\
\hline Balance Index Post Test & $62.45 \pm 6.17$ & $65.94 \pm 9.40$ & 0.35 \\
\hline ITN Pre Test & $138.22 \pm 34.12$ & $134.80 \pm 32.23$ & 0.82 \\
\hline ITN Post Test & $160.55 \pm 23.90$ & $172.30 \pm 29.36$ & 0.35 \\
\hline
\end{tabular}

Note. ${ }^{*} p<0.05$.

A significant difference is seen only in the agility test of the control and experimental groups, while the posttest results of the balance training group were found to be higher than those of the control group.

\section{Discussion}

Tennis is an explosive sport that requires multidirectional movements at short intervals. In addition, maintaining balance with the proprioceptive information coming from the lower extremity is important in tennis by the nature of the game. Therefore, proprioception is considerably important in tennis as tennis skills comprise complex movements that require improved balance ability (Mallilou et al. 2010). Determining the effect of balance training on other motoric qualities is significant in terms of performance enhancement. In this regard, the present study aimed to reveal the effect of balance training exercises on the strength, agility and balance performance along with the tennis skills of tennis players aged 10-14.

The findings of the present study show that an 8-week balance training program enhances agility and balance performance, improves tennis skills but does not affect vertical jump. The related literature includes studies reporting positive effects of balance training. In the study conducted with 29 amateur footballers aiming to determine the effects of balance and proprioception training on football-specific technical skills, Evangelos et al. (2012) found that balance training exercises improved technical skills. Cuğ et al. (2012) stated that 10-week training exercises on unstable ground enhanced core strength and joint proprioception and showed that it could bring about a long-term progresis as a result of the test they conducted 9 weeks after the training. Arumugam (2018) revealed that balance training improved the static and dynamic balance in 20 male football players, while there was no statistically significant improvement in the control group. Gioftsidou et al. (2012) created 3 different training groups in the training exercises done at different frequencies to improve balance and prevent injuries and revealed the positive effect of balance training held at least 3 
times a week. Heitkamp and ark. (2001) reported that balance training could increase strength as well as eliminating muscular imbalances. Yaggie and Campbell (2006) tested sport-related skills, vertical jump, shuttlerun and the time spent on the dominant leg on BOSU, and found that balance training contributed to posture maintenance with these skills, but there was uncertainty about the transfer of the skills to general functional improvement. Acar and Eler (2019) reported that balance training done by 10-12-year old girls and boys 3 times a week during 8 weeks generated statistically significant difference in the agility, speed and balance measures of the experimental group; Cerrah et al (2016) concluded that functional balance training 3 times a week enhanced adolescent footballers' balancing skills and stroke performances. Morera et al. (2017) suggested that proprioceptive training positively affected speed and agility performances of footballers. According to İri et al (2018), improving balance performance in 12-15-year-old wrestlers could enhance agility performance; and special balance training exercises to be taken would increase static-dynamic balance performance as well. Benis et al. (2016) stated that neuromuscular training increased postural control and lower extremity stability in women basketball players with the balance assessed with Y balance test; and including neuromuscular training in the exercise routines of volleyball players would raise joint awareness and reduce the risk of lower extremity injuries. Similarly, Kubal and Padwal (2016) revealed 6-week balance training could enhance agility performance. In summary, studies on balance training or performance in the literature have focused on its relationship with agility performance. Agility is defined as the ability to start explosively, slow down, change direction and speed up again while maintaining body control and minimizing any reduction in speed (Kubal and Padwal 2016). Maintaining body control is an important parameter for agility performance. It is possible to assert that balance training, with its significant contribution to body control, can have an improving effect on agility performance as well. In the findings of the present study, progress in agility performance is remarkable in the analyses both within and between groups. In addition, the apparent increase in agility performance with the enhancement of balance through balance training is considered to bring along improvement in tennis performance with its contributions to the practice of technical movements.

Contrary to the studies cited, Çelik et al. (2017) reported no statistical correlation between balance performance and agility performance in footballers. Verhagen et al. (2005) measured the center of pressure reaction of the ground reaction strength of a 5.5-week balance training program (using a power platform, determining postural swing) and concluded that it did not cause a decrease in the center of pressure deviation. Güler and Eniseler (2017) found that 6-week football-specific balance training enhanced promptness and power performance in footballers aged 15. The increase in promptness performance supports the findings of the present study while the increase in the vertical jump heights used to determine the power outcome is different. Manolopoulos et al. (2015) aimed to examine the effect of resistance training and the balance training performed along with resistance training on the strength, balance and jumping performance of footballers and found no difference between the two training practices in terms of balance and power enhancement. Moreover, a relationship is reported between muscle strength and balance. Specifically, they claimed that balance would considerably improve following muscular strength training and this improvement would be 
connected with the neuromuscular mechanisms that lead to a faster and more accurate mechanical reaction of the muscle in order to maintain balance. The results of this study reveal that balance training do not contribute to strength improvement. The period defined as sensitive for balance improvement is between the ages of 8 and 12. The greatest increases occur with the balance training exercises during this period and it reaches maturity at age 12-14. Strength, on the other hand, develops with the increased muscle mass along with growth and development (Bereket Yücel et al., 2020). The fact that no improvement was seen in strength performance while agility and balance performance enhanced through balance training is considered to have resulted from the growth periods of the 10-14-year-old tennis players composing the study sample. However, Erkmen et al. (2007) stated that balance performances may also change in different sports branches. This study was applied to 10-14 year-old tennis players. Study results may differ in athletes from different branches in the same age group.

\section{Conclusion}

In conclusion, the data obtained from the present study reveal that an 8-week balance training enhances balance, agility and tennis skills, but does not affect strength in tennis players aged 10-14. Tennis is a technical branch that involves the subsequent practice of multi-dimensional skills. It would not be sufficient to improve one single characteristic only for success in tennis. However, based on the findings of the present study, it could be asserted that balance training to be integrated in tennis training programs could help enhance agility and balance, which are among the most critical factors for success in tennis, as well as contributing to the development of tennis skills. For the reasons above, the present study is believed to help tennis trainers with their training plans and studies to be conducted in the future. It is suggested that future studies should focus on longer term training effects with larger participants and also different exercises could content balance trainings for different grounds.

\section{References}

Acar, H., \& Eler, N. (2019). The Effect of Balance Exercises on Speed andl Agility in Physical Education Lessons. Universal Journal of Educational Research, 7(1), 74-79. https://doi.org/ 10.13189/ujer.2019.070110

Arumugam, S. (2018). Effect of Proprioceptıve Trainıng on Dynamic and Static Balance among Soccer Players. Journal of Emerging Technologies and Innovative Research, 5(7), 312-316.

Barber-Westin, S. D., Hermeto, A. A., \& Noyes, F. R. (2010). A six-week neuromuscular training program for competitive junior tennis players. The Journal of Strength \& Conditioning Research, 24(9), 2372-2382. https://doi.org/10.1519/jsc.0b013e3181e8a47f

Benis, R., Bonato, M., \& Torre, A. L. (2016). Elite female basketball players' body-weight neuromuscular training and performance on the Y-balance test. Journal of Athletic Training, 51(9), 688-695. https://doi.org/10.4085/1062-6050-51.12.03 


\section{Macrothink}

Bereket Yücel, S., Bedestenlioğlu, M., RudarlıNalçakan, G., Hidayetoğlu, K., Ergin, E., \& Yarkın, G. (2020). In D. Mirzeoğlu (Ed.), TVF Voleybolda Antrenman Planlaması ve Periyodlaması (13-14 Yaşlar Iç̧in). Ankara: Spor Yayınevi ve Kitabevi.

Erkmen, N., Suveren, S., Göktepe, A. S., \& Yazıcıoğlu, K. (2007). Farkli branşlardaki sporcularin denge performanslarinin karşilaştirilmasi. Spormetre, V(3), 115-122.

Evangelos, B., Georgios, K., Konstantinos, A., Gissis, I., Papadopoulos, C., \& Aristomenis, S. (2012). Proprioception and balance training can improve amateur soccer players' technical skills. Journal of Physical Education and Sport, 12(1), 81.

Fernandez-Fernandez, J., Sanz-Rivas, D., \& Mendez-Villanueva, A. (2009). A review of the activity profile and physiological demands of tennis match play. Strength \& Conditioning Journal, 31(4), 15-26. https://doi.org/10.1519/SSC.0b013e3181ada1cb

Güler, Ö., \& Eniseler, N. (2017). The Effects Of Soccer Specıfic Balance Traınıng On Agılity And Vertical Jump Performances In Young Soccer Players. Journal of Physical Education \& Sports Science/Beden Egitimi ve Spor Bilimleri Dergisi, 11(3).

Gür, F., \& Ersöz, G. (2015). Kor antrenmanın 8-14 yaş grubu tenis sporcularının kor kuvveti, statik ve dinamik denge özellikleri üzerindeki etkisinin değerlendirilmesi. SPORMETRE Beden Ĕ̆itimi ve Spor Bilimleri Dergisi, 15(3), 129-138. https://doi.org/10.1501/Sporm_ 0000000317

Hrysomallis, C. (2011). Balance ability and athletic performance. Sports Medicine, 41(3), 221-232. https://doi.org/10.2165/11538560-000000000-00000

Kibele, A., \& Behm, D. G. (2009). Seven weeks of instability and traditional resistance training effects on strength, balance and functional performance. The Journal of Strength \& Conditioning Research, 23(9), 2443-2450. https://doi.org/10.1519/JSC.0b013e3181bf0489

Kubal, S., \& Padwal, D. (2016). The effect of balance training on agility in young cricketers. International Journal of Science and Research, 5(10), 485-492.

Lin, C. H., Lien, Y. H., Wang, S. F., \& Tsauo, J. Y. (2006). Hip and knee proprioception in elite, amateur, and novice tennis players. American Journal of Physical Medicine \& Rehabilitation, 85(3), 216-221. https://doi.org/10.1097/01.phm.0000200376.12974.41

Malliou, V. J., Beneka, A. G., Gioftsidou, A. F., Malliou, P. K., Kallistratos, E., Pafis, G. K., ... \& Douvis, S. (2010). Young tennis players and balance performance. The Journal of Strength \& Conditioning Research, 24(2), 389-393. https://doi.org/10.1519/JSC.0b013e3181c068f0

Manolopoulos, K., Gissis, I., Galazoulas, C., Manolopoulos, E., Patikas, D., Gollhofer, A., \& Kotzamanidis, C. (2016). Effect of combined sensorimotor-resistance training on strength, balance, and jumping performance of soccer players. The Journal of Strength \& Conditioning Research, 30(1), 53-59. https://doi.org/10.1519/JSC.0000000000001012

Moreira, N. B., Alves, R. C., Ferandes, D. Y., Prestes, L. F., Cassimiro, V., Da Silva, V. S., \& Preis, C. (2017). Effect of proprioceptive training and central stabilization in physical fitness 


\section{Macrothink}

in young soccer players. Journal of Physical Education and Sport, 17(2), 810. https://doi.org/ 10.7752/jpes.2017.02123

Moşoi, A. A., Gugu-Gramatopol, C., \& Botezatu, C. (2017). The Role Of Balance In Junnıors Tennis Game. Gymnasium, 13(2).

Okudur, A., \& Sanioğlu, A. (2012). 12 Yaş Tenisçilerde Denge ile Çeviklik İlişkisinin İncelenmesi. Selçuk Üniversitesi Beden Eğitimi ve Spor Bilimleri Dergisi, 14(2), 165-170.

Oliver, G. D., \& Di Brezzo, R. (2009). Functional balance training in collegiate women athletes. The Journal of Strength \& Conditioning Research, 23(7), 2124-2129. https://doi.org/ 10.1519/JSC.0b013e3181b3dd9e

Sannicandro, I., Cofano, G., Rosa, R. A., \& Piccinno, A. (2014). Balance training exercises decrease lower-limb strength asymmetry in young tennis players. Journal of Sports Science \& Medicine, 13(2), 397.

Šimek, S., Milanović, D., \& Jukić, I. (2007). The effects of proprioceptive training on jumping and agility performance. Kinesiology: International Journal of Fundamental and Applied Kinesiology, 39(2.), 131-141.

Tchórzewski, D., Bujas, P., \& Jankowicz-Szymańska, A. (2013). Body posture stability in ski boots under conditions of unstable supporting surface. Journal of Human Kinetics, 38(1), 33-44. https://doi.org/10.2478/hukin-2013-0043

Verhagen, E., Bobbert, M., Inklaar, M., van Kalken, M., van der Beek, A., Bouter, L., \& van Mechelen, W. (2005). The effect of a balance training programme on centre of pressure excursion in one-leg stance. Clinical Biomechanics, 20(10), 1094-1100. https://doi.org/ 10.1016/j.clinbiomech.2005.07.001

Vescovi, J. D., \& Vanheest, J. L. (2010). Effects of an anterior cruciate ligament injury prevention program on performance in adolescent female soccer players. Scandinavian Journal of Medicine \& Science in Sports, 20(3), 394-402. https://doi.org/10.1111/j.16000838. 2009.00963.x

Zech, A., Hübscher, M., Vogt, L., Banzer, W., Hänsel, F., \& Pfeifer, K. (2010). Balance training for neuromuscular control and performance enhancement: A systematic review. Journal of Athletic Training, 45(4), 392-403. https://doi.org/10.4085/1062-6050-45.4.392

\section{Copyright Disclaimer}

Copyright for this article is retained by the author(s), with first publication rights granted to the journal.

This is an open-access article distributed under the terms and conditions of the Creative Commons Attribution license (http://creativecommons.org/licenses/by/3.0/). 